\title{
ANALISIS IMPLEMENTASI PENGANGGARAN BERBASIS KINERJA TERHADAP AKUNTABILITAS PEMERINTAH DAERAH (Studi pada Instansi Pemerintah Daerah)
}

\author{
Endang Mahpudin \\ Universitas Singaperbangsa Karawang \\ (endang@indosat.net.id) \\ Made Panji Teguh Santoso \\ (mpt.santoso@gmail.com) \\ Syamsul Huda \\ (hudaunsika@gmail.com)
}

\begin{abstract}
The implementation of good governance is a prerequisite condition for every government to achieve people's aspirations. Every work unit is determined to reach agency accountability as the consequence of the mandate/responsibility it carries. This is done through considering the resources it manages in order to make government and development run effectively and efficiently, clean and responsibly. The research aims to find out and analyze the influence of performance-based budgeting performance on the accountability of government agencies within Karawang Regency. This research uses descriptive quantitative method in the form of statistical analysis, where the data is sourced from primary and secondary data coming from local government of Karawang Regency or other institutions related to this research. Descriptive method is a method that describes and presents an object as it is. Quantitative analysis in research design is intended to know the influence between independent variables with dependent variable. Based on the results of analysis and discussion, a conclusion can be drawn, that the implementation of performance-based budgeting affects the accountability of local government agencies within Karawang Regency. Improved implementation of performance-based budgeting will be followed by increased accountability of local government agencies.
\end{abstract}

Keywords: Performance-based Budgeting, Accountability, Local Government

\section{PENDAHULUAN}

Perwujudan Good

Governance merupakan prasyarat bagi setiap pemerintahan untuk mewujudkan aspirasi masyarakat dalam rangka meningkatkan kesejahteraan, untuk itu diperlukan pengembangan dan penerapan sistem pertanggungjawaban yang tepat, jelas dan legitimate sehingga penyelenggaraan pemerintah dan pembangunan dapat berlangsung secara berdaya guna dan berhasil guna, bersih, bertanggungjawab serta bebas dari korupsi, kolusi dan nepotisme. Untuk mewujudkan Good
Governance tersebut, pemerintah telah membuat peraturan perundang-undangan, antara lain:

1. Tap MPR Nomor IX Tahun 1998 tentang Penyelenggaraan Negara yang Bersih dan Bebas dari Korupsi, Kolusi dan Nepotisme.

2. Undang-undang Nomor 28 Tahun 1999 tentang Penyelenggaraan Negara yang Bebas dan Bersih dari Korupsi, Kolusi dan Nepotisme.

3. Peraturan Pemerintah Nomor 8 


$\begin{array}{llrr}\text { Tahun } 2006 & \text { tentang } & \text { Pelaporan } \\ \begin{array}{l}\text { Keuangan } \\ \text { Pemerintah }\end{array} & \text { dan } & \text { Kinerja } & \text { Instansi } \\ & & \end{array}$

4. Instruksi Presiden Nomor 7 Tahun 1999 tentang Akuntabilitas Instansi Pemerintah.

5. Peraturan Presiden Nomor 29 Tahun 2014 tentang Sistem Akuntabilitas Kinerja Instansi Pemerintah.

$\begin{array}{lrr}\text { 6. Keputusan } & \text { Kepala } & \text { Lembaga } \\ \text { Administrasi } & \text { Negara } & \text { Nomor } \\ \text { 239/IX/6/2003 } & \text { tentang } & \text { Perbaikan } \\ \text { Pedoman } & \text { Penyusunan } & \text { Laporan } \\ \text { Akuntabilitas } & \text { Kinerja } & \text { Instansi } \\ \text { Pemerintah. } & & \end{array}$

Peraturan perundang-undangan tersebut, menetapkan bahwa setiap lembaga pemerintah non departemen, pemerintah daerah, dan satuan kerja atau unit kerja di dalamnya, wajib membuat Laporan Akuntabilitas Kinerja Instansi Pemerintah secara berkala untuk disampaikan kepada atasannya. Keluaran utama dari Akuntabilitas ini berupa Laporan Akuntabilitas Kinerja Instansi Pemerintah (LAKIP), yang keberadaannya sangat penting sebagai umpan balik bagi penyelenggara pemerintahan. LAKIP memuat informasi yang relevan bagi pengguna laporan, yang diantaranya para pejabat dalam unsur perencanaan dan pengawasan.

Informasi yang terkandung dalam LAKIP ini memiliki 2 (dua) fungsi. Pertama, merupakan informasi kinerja yang disampaikan kepada publik, sebagai bagian dari pertanggungjawaban penerima amanat kepada pemberi amanat (masyarakat). Kedua, merupakan informasi kinerja yang menggambarkan segala permasalahan aktual yang bermanfaat sebagai dasar penetapan kebijakan selanjutnya. Kedua fungsi ini sebagai umpan balik yang dapat memberikan acuan kerja pemerintahan dalam upaya meningkatkan akuntabilitas instansi pemerintah, yang diharapkan dapat diperoleh dari peningkatan perencanaan maupun pelaksanaan pembangunan.

Pencapaian akuntabilitas instansi merupakan tekad yang ingin dicapai oleh setiap unit kerja sebagai penerima amanah/tanggungjawab dalam suatu periode tertentu dengan mempertimbangkan sumberdaya yang dikelolanya. Penetapan akuntabilitas instansi pemerintah ini merupakan suatu penetapan targettarget kinerja yang akan diwujudkan oleh seorang pejabat penerima amanah kepada atasan langsungnya. Penetapan target akuntabilitas ini akan menggambarkan pencapaian kinerja yang akan diwujudkan oleh suatu instansi pemerintah dalam suatu periode tertentu (umumnya dalam satu tahun) dengan mempertimbangkan sumberdaya yang dikelolanya.

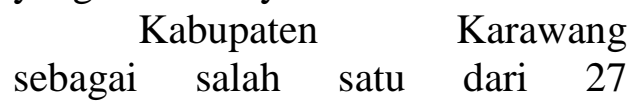
Kabupaten/Kota di Jawa Barat telah berupaya semaksimal mungkin dalam menerapkan prinsip good governance dengan salah satunya mengharuskan setiap Satuan Kerja Pemerintah Daerah (SKPD) di lingkungan Pemerintah Kabupaten Karawang membuat laporan keuangan dan kinerja dalam bentuk Laporan Akuntabilitas Kinerja Instansi Pemerintah untuk disampaikan kepada atasan, tidak terkecuali untuk Pemerintah Daerah Kabupaten Karawang. Pemerintah Daerah Kabupaten Karawang sebagai salah satu dari 27 Kabupaten/Kota di Provinsi Jawa Barat yang berfungsi sebagai unsur pelaksana daerah otonom pemerintahan daerah dan berkedudukan di bawah serta bertanggungjawab langsung kepada Gubernur Jawa Barat dengan 
melaksanakan kewenangan/urusan di bidang pemerintahan.

Kabupaten Karawang memiliki visi yaitu "Karawang yang Mandiri, Maju, Adil dan Makmur". Sedangkan misinya yaitu 1) Mewujudkan Aparatur Pemerintah Daerah yang Bersih dan Berwibawa, 2) Mewujudkan Kabupaten Karawang yang Berdaya Saing, 3) Mewujudkan Masyarakat Demokratis Berlandaskan Hukum, 4) Mewujudkan Kabupaten Karawang yang Asri dan Lestari, dan 5) Membangun Kabupaten Karawang melalui Penguatan Desa. Sebagai bentuk pertanggungjawaban pelaksanaan tugas-tugas pemerintahan daerah di Kabupaten Karawang, Satuan Kerja Perangkat Daerahnya (SKPD) wajib menyusun laporan pertanggungjawaban sebagai bentuk pelaksanaan akuntabilitas instansi pemerintah. Pelaksanaan akuntabilitas setiap SKPD berpedoman kepada Keputusan Kepala Lembaga Administrasi Negara Nomor 239/IX/6/2003 tentang Perbaikan Pedoman Penyusunan Laporan Akuntabilitas Kinerja Instansi Pemerintah, dan Peraturan Pemerintah Nomor 8 Tahun 2006 tentang Pelaporan Keuangan dan Kinerja Instansi Pemerintah. Pengukuran akuntabilitas ini diperoleh berdasarkan tingkat pencapaian kinerja, sasaran program/kegiatan, dengan membandingkan antara rencana kegiatan dengan realisasi kegiatan serta memperhatikan indikator-indikator yang mempengaruhinya, meliputi indikator masukan (input), hasil (output), dan keluaran (outcome).

Hasil pengukuran kinerja tersebut dilakukan dengan menganalisis kinerja untuk mengetahui keberhasilan dan atau kegagalan dalam mencapai sasaran strategi, serta sebab-sebab tercapai tidaknya kinerja yang diharapkan. Dalam konteks itu, dari Penyusunan Laporan Akuntabilitas Kinerja Instansi Pemerintah tentu dapat dinilai keberhasilan atau bobot kinerja unit-unit kerja (SKPD) Pemerintah Daerah dalam hal melaksanakan kebijakan anggaran kegiatan.
Berdasarkan hasil Laporan Akuntabilitas Kinerja Instansi Pemerintah Tahun 2016 yang tertera dalam Laporan Pertanggungjawaban Pemerintah Daerah Kabupaten Karawang, diketahui bahwa tidak semua penggunaan anggaran mencapai indikator kinerja anggaran secara optimal. Artinya terdapat sejumlah kegiatan di Pemerintah Daerah Kabupaten Karawang yang menunjukkan bahwa antara rencana anggaran yang ditetapkan dengan realisasi anggaran kegiatan terdapat ketidaktercapaian. Hal ini memperlihatkan tidak semua penggunaan anggaran mencapai indikator kinerja anggaran secara optimal. Artinya terdapat sejumlah kegiatan di Pemerintah Daerah Kabupaten Karawang yang menunjukkan bahwa antara rencana anggaran yang ditetapkan dengan realisasi anggaran kegiatan terdapat ketidaktercapaian.

$\begin{array}{cll}\text { Belanja } & \text { Daerah } & \text { yang } \\ \text { diklasifikasikan } & \text { menurut } & \text { jenis }\end{array}$ belanja dibagi ke dalam kelompok Belanja Tidak Langsung dan Belanja Langsung. Jenis belanja yang tidak Langsung adalah belanja pegawai untuk membayar gaji dan tunjangan PNS, belanja bunga, belanja subsidi, belanja hibah, belanja bantuan sosial, belanja bagi hasil, bantuan keuangan dan belanja tak terduga. Sedangkan belanja Langsung adalah belanja yang langsung dapat diukur dengan hasil dari suatu program dan kegiatan yang dianggarkan, termasuk efisiensi dalam pencapaian keluaran dari hasil tersebut, yaitu belanja pegawai untuk membayar honorarium/upah kerja, belanja barang dan jasa dan belanja modal.

$\begin{array}{ccc}\text { Pada } & \text { sejumlah } & \text { kegiatan } \\ \text { ternyata } & \text { bobot } & \text { Laporan }\end{array}$


Akuntabilitas Kinerja Instansi Pemerintah Daerah Kabupaten Karawang menunjukkan capaian indikator kinerja anggaran pada sejumlah kegiatan Pemerintah Daerah Kabupaten Karawang dapat dianggap sebagai suatu fenomena manajemen keuangan daerah yang tidak berdiri sendiri. Artinya terdapat sejumlah faktor yang berkorelasi atau berpengaruh terhadap pencapaian indikator kinerja anggaran kegiatan yang tersusun dalam Laporan Akuntabilitas Kinerja Instansi Pemerintah Daerah Kabupaten Karawang, diantaranya adalah penganggaran berbasis kinerja.

Berkaitan dengan penganggaran, Mardiasmo 2004 (dalam Asmoko, 2006:2) menyatakan anggaran sektor publik terutama pemerintah penting, karena: 1) Anggaran merupakan alat bagi pemerintah untuk mengarahkan pembangunan sosialekonomi, menjamin kesinambungan, dan meningkatkan kualitas hidup masyarakat; 2) adanya kebutuhan dan keinginan masyarakat yang tak terbatas dan terus berkembang, sedangkan sumber daya yang ada terbatas; 3) untuk meyakinkan bahwa pemerintah telah bertanggung jawab terhadap rakyat.

Seiring dengan adanya reformasi pengelolaan sektor publik yang ditandai dengan munculnya era New Public Management (NPM), telah mendorong adanya usaha untuk mengembangkan pendekatan yang lebih sistematis dalam penganggaran sektor publik. Terdapat 4 (empat) jenis pendekatan penganggaran di sektor publik dengan penekanan yang berbeda-beda untuk setiap pendekatan tersebut. Keempat pendekatan dalam penganggaran ini adalah line item budgeting, performance budgeting, program budgeting, dan zero-based budgeting (Kluvers, 1999, dalam Asmoko, 2006:2). Pemerintah Indonesia berdasarkan UndangUndang Nomor 32 dan 33 Tahun 2004, serta Undang-Undang Nomor 17 Tahun 2003 tentang Keuangan Negara telah menetapkan penggunaan pendekatan penganggaran berbasis prestasi kerja atau kinerja dalam proses penyusunan anggaran. Penganggaran Berbasis Kinerja (PBK) merupakan suatu pendekatan dalam penyusunan anggaran yang didasarkan pada kinerja atau prestasi kerja yang ingin dicapai.

Adanya faktor penganggaran berbasis kinerja yang berpengaruh terhadap akuntabilitas instansi pemerintah, tidak hanya menjadi fenomena yang ada di Kabupaten Karawang, tetapi juga terjadi di daerah lain. Hasil penelitian yang telah dilakukan oleh Taufik Djungdjung Muda pada Sekretariat Kota Kotamadya Jakarta Selatan pada Tahun 2015 membuktikan bahwa perencanaan anggaran berpengaruh kuat terhadap akuntabilitas Sekretariat Kota Kotamadya Jakarta Selatan, artinya bahwa kecermatan, ketepatan dan transparansi perencanaan anggaran meningkat maka akan dibarengi dengan peningkatan akuntabilitas instansi pemerintah pada Sekretariat Kota Kotamadya Jakarta Selatan. Kemudian pelaksanaan anggaran berpengaruh kuat terhadap akuntabilitas Sekretariat Kota Jakarta Selatan, artinya bahwa jika efisiensi dan transparansi pelaksanaan anggaran ditingkatkan maka akan meningkat akuntabilitas instansi pemerintah pada Sekretariat Kota Jakarta Selatan.

Kesamaan dalam penelitian yang dilakukan ini terutama berkaitan dengan penggunaan variabel akuntabilitas instansi pemerintah, sedangkan perbedaannya terutama dalam penggunaan variabel penyebabnya yang dalam penelitian ini digunakan faktor penganggaran berbasis kinerja.

Selain itu, penelitian lainnya yang menyangkut penganggaran 
berbasis kinerja dilakukan oleh Hindri Asmoko (2016) dengan judul Pengaruh Penganggaran Berbasis Kinerja terhadap Efektivitas Pengendalian, memperlihatkan bahwa penganggaran berbasis kinerja berpengaruh positif secara signifikan terhadap efektivitas pengendalian keuangan dan efektivitas pengendalian kinerja. Hal ini memperlihatkan bahwa semakin tinggi penerapan penganggaran berbasis kinerja akan menyebabkan lebih efektifnya pengendalian kinerja Pemerintah Kabupaten Klaten dan Pemerintah Kabupaten Sragen, Propinsi Jawa Tengah. Kesamaan dalam penelitian yang dilakukan ini terutama berkaitan dengan penggunaan variabel penganggaran berbasis kinerja, sedangkan perbedaannya terutama dalam penggunaan variabel akibatnya yang dalam penelitian ini digunakan faktor akuntabilitas instansi pemerintah.

Secara khusus di Kabupaten Karawang, diantara sejumlah faktor yang mempengaruhi akuntabilitas kegiatan Pemerintah Daerah Kabupaten Karawang tersebut, dapat diasumsikan bahwa penganggaran berbasis kinerja berpengaruh positif terhadap akuntabilitas instansi pemerintah Daerah Kabupaten Karawang. Asumsi yang dikemukakan ini dapat didukung dengan penjelasan sebagai berikut:

1. Akuntabilitas instansi pemerintah pada dasarnya dapat dianggap sebagai hasil dari pencapaian yang diperoleh dari implementasi penganggaran berbasis kinerja. Implementasi penganggaran berbasis kinerja yang diperoleh dari perencanaan anggaran, tersusun dalam bentuk Rencana Kegiatan Anggaran (RKA) dan kemudian disetujui menjadi Dokumen Pelaksanaan Anggaran (DPA). Realisasi rencana anggaran inilah yang tercatat dalam penyusunan Laporan Akuntabilitas Kinerja Instansi Pemerintah. Dengan demikian, diantara perencanaan anggaran dengan Laporan Akuntabilitas Kinerja Instansi
Pemerintah terjalin suatu mekanisme hubungan fungsional yang mempengaruhi. Dalam konteks ini, perencanaan anggaran dapat dipandang sebagai input managerial dan LAKIP dapat dipandang sebagai output managerial.

2. Implementasi anggaran kegiatan diatur dengan prosedur dan tata cara pengelolaan pos-pos keuangan publik. Implementasi anggaran ini merupakan proses penggunaan pos-pos anggaran kegiatan yang kemudian perlu dideskripsikan

dipertanggungjawabkan dalam penyusunan Laporan Akuntabilitas Kinerja Instansi Pemerintah. Dengan demikian diantara pelaksanaan anggaran dengan Laporan Akuntabilitas Kinerja Instansi Pemerintah terjalin mekanisme hubungan fungsional yang mempengaruhi. Dalam konteks ini pelaksanaan anggaran dapat dipandang sebagai process managerial dan LAKIP dapat dipandang sebagai output managerial.

3. Dalam penganggaran sektor publik, implementasi penganggaran berbasis kinerja dapat dianggap sebagai variabel yang mendahului, dan akuntabilitas instansi pemerintah dapat dianggap sebagai variabel konsekuensi. Implementasi penganggaran berbasis kinerja ini dapat diukur berdasarkan prinsip-prinsip pokok dalam siklus anggaran yang terdiri dari persiapan anggaran, ratifikasi anggaran, pelaksanaan anggaran, serta pelaporan dan evaluasi anggaran. Karena prinsip-prinsip pokok anggaran ini merupakan siklus anggaran, maka antara 
variabel implementasi penganggaran tersebut yang terdiri dari persiapan anggaran, ratifikasi anggaran, pelaksanaan anggaran, serta pelaporan dan evaluasi terjalin suatu hubungan keterkaitan.

Penelitian ini dibatasi pada implementasi penganggaran berbasis kinerja yang diukur melalui persiapan anggaran, pelaksanaan anggaran, serta evaluasi dan pelaporan anggaran yang memperhatikan input, output, dan outcome yang jelas dan terukur (Henley et. all, 1990 dalam Mardiasmo, 2005: 70 dan Permendagri No. 13 Tahun 2006). Sedangkan untuk akuntabilitas instansi yang diteliti dibatasi pada akuntabilitas keuangan, akuntabilitas manfaat dan akuntabilitas prosedural (LAN RI dan BPKP, 2001: 29).

Persoalan mendasar bagi Pemerintah Daerah Kabupaten Karawang dalam mewujudkan terciptanya akuntabilitas instansi pemerintah sebagai salah satu prasyarat untuk terciptanya pemerintahan yang baik, ditentukan oleh implementasi penganggaran berbasis kinerja yang terdiri dari persiapan anggaran, ratifikasi anggaran, pelaksanaan anggaran, serta pelaporan dan evaluasi anggaran. Adapun tujuan penelitian yang akan dilakukan ini yaitu untuk mengetahui dan menganalisis besarnya pengaruh implementasi penganggaran berbasis kinerja terhadap akuntabilitas instansi pemerintah pada Pemerintah Daerah Kabupaten Karawang.

\section{KERANGKA TEORITIS DAN HIPOTESIS}

Anggaran tidak dapat dipisahkan dari sistem perencanaan, di samping memang anggaran itu sendiri merupakan sebuah rencana. Dalam suatu sistem perencanaan, anggaran merupakan muara akhir. Perencanaan anggaran dimulai dari perencanaan jangka panjang, perencanaan jangka menengah, dan perencanaan tahunan. Anggaran merupakan salah satu instrumen utama dalam melaksanakan suatu program atau kegiatan yang telah ditetapkan. Selain anggaran, instrumen lain untuk melaksanakan suatu kegiatan diantaranya sumber daya manusia (SDM), peralatan, metodologi pelaksanaan dan lainlain. Namun instrumen diluar anggaran tersebut akan dapat berjalan jikalau ada dukungan anggaran. Jika suatu kegiatan diajukan untuk dilaksanakan, tetapi ternyata tidak didukung oleh ketersediaan anggaran, maka dapat dikatakan bahwa sebetulnya anggaran merupakan instrumen utama dalam melaksanakan suatu kegiatan.

Anggaran berbasis kinerja merupakan perencanaan kinerja tahunan secara terintegrasi yang menunjukkan hubungan antara tingkat pendanaan program dan hasil yang diinginkan dari program tersebut. Definisi penganggaran berbasis kinerja dikemukakan oleh Bastian (2016:52) yang menyatakan bahwa: "anggaran dengan pendekatan kinerja adalah suatu sistem anggaran yang mengutamakan upaya pencapaian hasil kerja atau output dari perencanaan alokasi biaya atau input yang ditetapkan." Hal ini menunjukkan bahwa anggaran kinerja yang efektif lebih dari sebuah objek anggaran program atau organisasi dengan outcome yang telah diantisipasi sebelumnya. Sebagai variasi antara perencanaan dan kejadian sebenarnya, manajer dapat menentukan input-input resource dan bagaimana input-input tersebut berhubungan dengan outcome untuk menentukan efektivitas dan efisiensi program.

$$
\text { Penganggaran berbasis }
$$
kinerja merupakan acuan yang 
dibutuhkan guna mencapai tujuan masa depan. Faktor dominan yang terdapat dalam proses penganggaran (Mardiasmo, 2015:69) adalah:

1. Tujuan dan target yang hendak dicapai

2. Ketersediaan sumber daya (faktor-faktor produksi yang dimiliki pemerintah)

3. Waktu yang dibutuhkan untuk mencapai tujuan dan target

4. Faktor-faktor lain yang mempengaruhi anggaran, seperti: munculnya peraturan pemerintah yang baru, fluktuasi pasar, perubahan sosial dan politik, bencana alam, dan sebagainya.

Menurut Mardiasmo (2015:69), pengelolaan keuangan publik melibatkan beberapa aspek, yaitu aspek penganggaran, aspek akuntansi, aspek pengendalian, dan aspek auditing. Aspek penganggaran mengantisipasi pendapatan dan belanja (revenues and expenditures), sedangkan aspek akuntansi terkait dengan proses mencatat, mengolah, dan melaporkan segala aktivitas penerimaan dan pengeluaran (receipts and disbursements) atas dana pada saat anggaran dilaksanakan. Menurut Mardiasmo (2015:69), kedua aspek tersebut dianggap penting dalam manajemen keuangan publik. Namun, di antara kedua aspek tersebut aspek penganggaran dianggap sebagai isu sentral bila dipandang dari sisi waktu. Sedangkan aspek akuntansi lebih bersifat retrospective (pencatatan masa lalu), maka aspek penganggaran lebih bersifat prospective atau anticipatory (perencanaan masa yang akan datang). Karena aspek penganggaran dianggap sebagai isu sentral, maka para manajer publik perlu mengetahui prinsip-prinsip pokok yang ada pada siklus anggaran sebagai dimensi dalam pengukuran penganggaran berbasis kinerja.

Lebih lanjut, Waluyo (2017: 224) menjelaskan bahwa performance budget atau anggaran berbasis kinerja pada dasarnya adalah sistem penyusunan dan pengelolaan anggaran daerah yang berorientasi pada pencapaian hasil kinerja dimana kinerja tersebut harus berorientasi pada kepentingan publik. Dalam performance budget, anggaran daerah diharapkan benarbenar dapat mencerminkan kepentingan masyarakat daerah terhadap pengelolaan keuangan daerah yang ekonomis, efisien, dan efektif (menerapkan prinsip value of money) (Waluyo, 2007: 218). Sistem penyusunan dan pengelolaan anggaran daerah ini diwujudkan dalam siklus anggaran yang terdiri dari 4 (empat) tahap, yaitu: persiapan anggaran, ratifikasi, implementasi, serta pelaporan dan evaluasi (Henley et al., 1990, dalam Mardiasmo, 2005:69). Dalam penganggaran di SKPD, tahapan siklus anggaran yang relevan adalah persiapan anggaran, pelaksanaan/implementasi anggaran, serta pelaporan dan evaluasi anggaran. Tahap ratifikasi tidak dilakukan mengingat SKPD merupakan entitas akuntansi, namun bukan sebagai entitas pelaporan. Dengan demikian, sebagaimana dasar teori di atas, pelaksanaan tahapan-tahapan dalam siklus anggaran merupakan wujud dari penerapan sistem penyusunan dan pengelolaan anggaran daerah berbasis kinerja. Dalam penerapannya dicirikan oleh adanya orientasi pada pencapaian hasil kinerja sesuai kepentingan publik serta pengelolaannya yang ekonomis, efisien, dan efektif.

Pada dasarnya, akuntabilitas adalah pemberian informasi dan pengungkapan (disclosure) atas aktivitas dan kinerja finansial kepada pihak-pihak yang berkepentingan (Schiavo-Campo dan Tomasi, 2009). Pemerintah, baik pusat maupun daerah, harus dapat menjadi subyek pemberi 
informasi dalam rangka pemenuhan hak-hak publik yaitu hak untuk tahu, hak untuk diberi informasi, dan hak untuk didengar aspirasinya. Berkaitan dengan akuntabilitas instansi pemerintah, LAN RI dan BPKP (2011:29) menjelaskan pembagian akuntabilitas yang terdiri dari:

1. Akuntabilitas Keuangan.

2. Akuntabilitas Manfaat.

3. Akuntabilitas Prosedural.

American Accounting Association, 1970 (dalam Glynn, 2003) menyatakan bahwa tujuan akuntansi pada organisasi sektor publik adalah memberikan informasi yang diperlukan agar dapat mengelola suatu operasi dan alokasi sumber daya yang dipercayakan kepada organisasi secara tepat, efisien, dan ekonomis, serta memberikan informasi untuk melaporkan pertanggungjawaban pelaksanaan pengelolaan tersebut serta melaporkan hasil operasi dan penggunaan dana publik. Dengan demikian, akuntansi sektor publik terkait dengan penyediaan informasi untuk pengendalian manajemen dan akuntabilitas.

Keterkaitan antara implementasi anggaran berbasis kinerja dengan akuntabilitas instansi pemerintah dapat terlihat berdasarkan penjelasan yang dikemukakan oleh Bastian (2006:54) yang menyatakan bahwa upaya untuk menciptakan sistem pengelolaan anggaran berbasis kinerja diharapkan akan mampu memenuhi berbagai tuntutan dan kebutuhan masyarakat, yaitu terbentuknya semangat desentralisasi, demokratisasi, transparansi, dan akuntabilitas dalam proses penyelenggaraan pemerintahan pada umumnya dan proses pengelolaan Keuangan Daerah pada khususnya. Hal ini memperlihatkan bahwa implementasi penganggaran berbasis kinerja akan berpengaruh terhadap akuntabilitas instansi. Dengan implementasi penganggaran berbasis kinerja yang terukur melalui persiapan anggaran, pelaksanaan anggaran, serta evaluasi dan pelaporan anggaran yang berorientasi pada pencapaian hasil kinerja sesuai kepentingan publik dan dikelola secara ekonomis, efisien, dan efektif (memperhatikan input, output, dan outcome yang jelas dan terukur) maka akuntabilitas instansi akan optimal. Atau dengan kata lain, implementasi anggaran berbasis kinerja yang diwujudkan dalam pelaksanaan tahapan- tahapan dalam siklus anggaran yang berorientasi pada hasil kinerja sesuai kepentingan publik serta memperhatikan prinsip value of money akan mampu menghasilkan akuntabilitas instansi sebagaimana diharapkan. Selanjutnya, dengan optimalnya akuntabilitas instansi yang terukur melalui akuntabilitas keuangan, akuntabilitas manfaat dan akuntabilitas prosedural, maka akan mendorong terciptanya good governance atau tata kelola pemerintahan yang baik.

Dalam pengaruhnya terhadap akuntabilitas instansi, implementasi penganggaran berbasis kinerja yang terukur melalui tahapan siklus anggaran sesuai dengan prinsip akuntabilitas dalam pengelolaan keuangan daerah yaitu bahwa proses penganggaran mulai dari perencanaan, pelaksanaan, pelaporan dan evaluasinya harus benar-benar dapat dipertanggungjawabkan kepada masyarakat (Waluyo, 2017: 218). Masyarakat tidak hanya memiliki hak untuk mengetahui anggaran tersebut, namun juga berhak menuntut pertanggungjawaban atas setiap dana masyarakat yang dialokasikan atas rencana, pelaksanaan, ataupun pelaporan dan evaluasi atas anggaran.

Berdasarkan kerangka pemikiran di atas, pengaruh 
implementasi penganggaran berbasis kinerja terhadap akuntabilitas instansi pemerintah kerangka pemikiran sebagai berikut. dapat dikemukakan dalam bentuk gambar

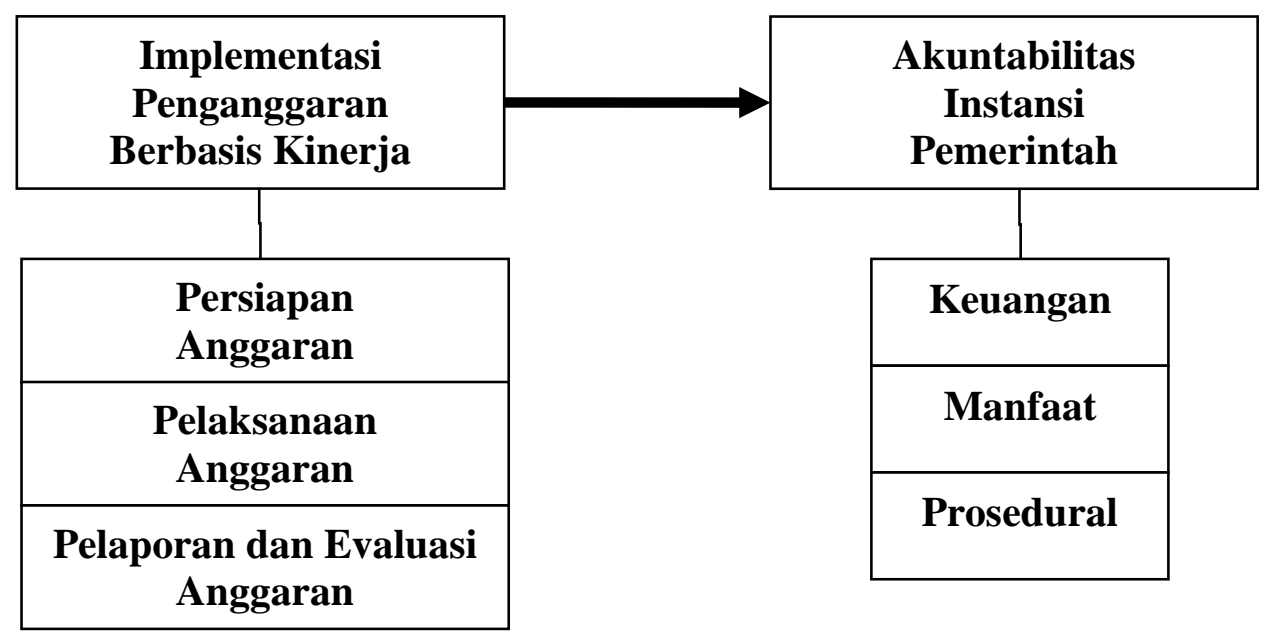

Gambar 1

Kerangka Pemikiran Pengaruh Implementasi Penganggaran Berbasis Kinerja terhadap Akuntabilitas Instansi Pemerintah

Berdasarkan kerangka pemikiran yang telah dikemukakan, maka hipotesis yang akan diuji dalam penelitian ini ditetapkan sebagai berikut:

"Implementasi penganggaran berbasis kinerja berpengaruh terhadap akuntabilitas instansi Pemerintah Daerah Kabupaten Karawang."

\section{METODOLOGI}

Metode penelitian yang digunakan dalam penelitian ini adalah metode deskriptif analitis. Pengertian dari metode deskriptif menurut Nazir (2015:54) adalah: "Suatu metode dalam meneliti status sekelompok manusia, suatu objek, suatu set kondisi, suatu sistem pemikiran ataupun suatu kelas peristiwa pada masa sekarang". Berdasarkan tujuannya, penelitian ini merupakan penelitian eksplanatori karena bertujuan untuk menjelaskan hubungan kausal antara variabel Implementasi Penganggaran Berbasis Kinerja dengan Akuntabilitas Instansi Pemerintah serta menguji hipotesis. Menurut pengumpulan datanya, penelitian ini termasuk ke dalam penelitian sensus karena meneliti seluruh anggota populasi SKPD di lingkungan Pemda Kabupaten Karawang.

\section{HASIL DAN PEMBAHASAN}

Data penelitian diperoleh dari jawaban para responden. Responden dalam penelitian ini merupakan seluruh Satuan Kerja Perangkat Daerah (SKPD) Pemerintah Daerah Kabupaten Karawang yang berjumlah 36 SKPD. Penelitian ini lebih difokuskan kepada pengaruh implementasi penganggaran berbasis kinerja terhadap akuntabilitas instansi Pemerintah Daerah Kabupaten Karawang.

Kuesioner yang disebarkan terdiri dari 3 (tiga) bagian, yaitu bagian pertama berisi mengenai identitas responden, bagian kedua berisi pertanyaan tentang implementasi penganggaran berbasis kinerja dan bagian ketiga berisi pertanyaan tentang akuntabilitas instansi Pemerintah Daerah Kabupaten Karawang, di mana pertanyaannya sudah ditentukan oleh peneliti dan 
jawaban pertanyaan mengenai implementasi penganggaran berbasis kinerja dan akuntabilitas instansi pemerintah daerah menggunakan Skala Likert, yaitu berisi lima tingkatan jawaban yang menggunakan skala jenis ordinal.

Pada penelitian ini peneliti membuat pertanyaan sebanyak 44 pertanyaan, yang terdiri dari 8 pertanyaan tentang identitas responden, 19 pertanyaan tentang implementasi penganggaran berbasis kinerja dan 17 pertanyaan tentang akuntabilitas instansi Pemerintah Daerah Kabupaten Karawang.

Berdasarkan hasil pengumpulan data kuesioner dapat diketahui mayoritas responden berdasarkan jenis kelamin yaitu laki-laki $(66,7 \%)$, berumur 51 - 55 tahun (36.11\%), pendidikan S1 (55.56\%), Eselon III $(47.22 \%)$, Satuan Kerja Perangkat Daerah (SKPD) Dinas (50.00\%), Jabatan Kepala Bidang (27.78\%) dan masa kerja > 20 tahun $(47.22 \%)$.

Hasil pengujian validitas untuk variabel implementasi penganggaran berbasis kinerja dan akuntabilitas instansi pemerintah daerah di Kabupaten Karawang, dengan alat bantu software IBM SPSS Ver. 24, menunjukkan bahwa semua item pernyataannya dapat dinyatakan valid, dengan koefisien korelasi di atas nilai batas 0,200; yang berarti bahwa setiap item pernyataan dapat dipergunakan untuk mengukur tingkat implementasi penganggaran berbasis kinerja Satuan Kerja Perangkat Daerah (SKPD) Pemerintah Daerah Kabupaten Karawang. Hasil uji validitas item-item pernyataan pada kuesioner variabel akuntabilitas instansi pemerintah daerah menunjukkan bahwa semua item dapat dinyatakan valid, dengan koefisien korelasi di atas nilai batas 0,200; yang berarti bahwa setiap item pernyataan dapat dipergunakan untuk mengukur tingkat akuntabilitas instansi pemerintah daerah
Satuan Kerja Perangkat Daerah (SKPD) Pemerintah Daerah Kabupaten Karawang.

Hasil uji reliabilitas untuk setiap variabel penelitian yang dipergunakan menunjukkan bahwa setiap variabel penelitian yang dipergunakan telah memenuhi kategori reliabel, dengan nilai koefisien Spearman-Brown di atas nilai batas 0,200. Hal ini memberikan informasi bahwa jawaban responden terhadap kuesioner yang dipergunakan memperlihatkan kekonsistenan, sehingga hasil perolehan skor jawaban kuesioner dapat dipergunakan dan dianalisis lebih lanjut.

Deskripsi data yang akan disajikan pada bagian ini adalah deskripsi data masing-masing variabel penelitian yang terdiri atas satu variabel bebas yaitu Implementasi Penganggaran Berbasis Kinerja (X) dan variabel terikat yaitu Akuntabilitas Instansi Pemerintah Daerah (Y). Deskripsi data disajikan untuk masingmasing variabel secara berturut-turut dengan uraian sebagai berikut:

Dari distribusi data Implementasi Penganggaran Berbasis Kinerja (X) yaitu terlebih dahulu menentukan skor maksimal sebesar 180, skor minimal sebesar 36 , nilai median sebesar 108 nilai kuartil 1 sebesar 72 dan nilai kuartil 3 sebesar 144. Kemudian membuat batas-batas skor untuk masing-masing kategori.

Range skor dari keempat kategori :

Tinggi: (Kuartil $3 \leq \mathrm{x} \leq$ Skor maksimal) $\quad=144-180$

Sedang: $($ Median $\leq \mathrm{x}<$ Kuartil 3) $=$ $108-144$

Rendah: (Kuartil $1 \leq \mathrm{x}<$ Median) $=72-108$

Sangat Rendah: (Skor Minimal $\leq \mathrm{x}<$ Kuartil 1) $=36-72$ 
Tabel 1

Distribusi Skor Implementasi Penganggaran Berbasis Kinerja

\begin{tabular}{|c|c|c|c|c|}
\hline No. & Item & Skor & Persentase & Kategori \\
\hline 1 & $\begin{array}{l}\text { Dalam persiapan anggaran, SKPD melakukan taksiran anggaran } \\
\text { pengeluaran yang paling ekonomis atas dasar taksiran penerimaan } \\
\text { yang telah dilakukan }\end{array}$ & 86 & 47,8 & Rendah \\
\hline 2 & $\begin{array}{l}\text { Sebelum melakukan taksiran anggaran pengeluaran, SKPD } \\
\text { melakukan taksiran penerimaan berdasarkan kinerja anggaran } \\
\text { sebelumnya }\end{array}$ & 109 & 60,6 & Sedang \\
\hline 3 & $\begin{array}{l}\text { Dalam persiapan anggaran SKPD, penganggaran mengacu pada } \\
\text { kinerja yang diharapkan dalam RENSTRA (Rencana Strategis ) dan } \\
\text { Renja }\end{array}$ & 171 & 95 & Tinggi \\
\hline 4 & $\begin{array}{l}\text { Dalam persiapan anggaran SKPD, penganggaran dilakukan } \\
\text { berdasarkan prioritas manfaatnya sesuai dengan tuntutan dan } \\
\text { kebutuhan public }\end{array}$ & 160 & 88,9 & Tinggi \\
\hline 5 & $\begin{array}{l}\text { Dalam persiapan anggaran SKPD, penganggaran atas sasaran yang } \\
\text { hendak dicapai didasarkan atas tingkat efisiensinya }\end{array}$ & 162 & 90 & Tinggi \\
\hline 6 & $\begin{array}{l}\text { Dalam persiapan anggaran SKPD, penganggaran mengacu pada } \\
\text { hasil evaluasi peningkatan kinerja anggaran periode sebelumnya }\end{array}$ & 163 & 90,5 & Tinggi \\
\hline 7 & $\begin{array}{l}\text { Dalam melakukan penganggaran, SKPD mengakomodasi masukan- } \\
\text { masukan dan aspirasi masyarakat }\end{array}$ & 120 & 66,7 & Sedang \\
\hline 8 & $\begin{array}{l}\text { Dalam persiapan anggaran SKPD, penganggaran didasarkan pada } \\
\text { daya dukung pembiayaan oleh pemerintah pusat dalam mencapai } \\
\text { kinerja yang diharapkan }\end{array}$ & 97 & 53,89 & Rendah \\
\hline 9 & $\begin{array}{l}\text { Dalam persiapan anggaran SKPD, penganggaran didasarkan pada } \\
\text { daya dukung sumber daya pemerintah daerah dalam mencapai } \\
\text { kinerja yang diharapkan }\end{array}$ & 136 & 75,5 & Sedang \\
\hline 10 & $\begin{array}{l}\text { Dalam persiapan anggaran SKPD, penganggaran didasarkan pada } \\
\text { kajian atas kondisi sosial ekonomi masyarakat }\end{array}$ & 125 & 69,4 & Sedang \\
\hline 11 & $\begin{array}{l}\text { Dalam persiapan anggaran SKPD, penganggaran didasarkan pada } \\
\text { kajian atas perkembangan tuntutan dan kebutuhan masyarakat }\end{array}$ & 128 & 71,1 & Sedang \\
\hline 12 & $\begin{array}{l}\text { Pemanfaatan sistem informasi akuntansi daerah dalam pengukuran } \\
\text { dan pengendalian kinerja anggaran }\end{array}$ & 157 & 87,2 & Tinggi \\
\hline 13 & $\begin{array}{l}\text { Pemanfaatan SAKIP dalam pengukuran dan pengendalian hasil } \\
\text { kerja program/kegiatan }\end{array}$ & 166 & 92,2 & Tinggi \\
\hline 14 & $\begin{array}{l}\text { Penerapan sistem akuntansi yang dapat diandalkan untuk } \\
\text { pengendalian anggaran }\end{array}$ & 129 & 71,6 & Sedang \\
\hline 15 & $\begin{array}{l}\text { Dalam pelaksanaan anggaran, SKPD mampu menerapkan sistem } \\
\text { pengendalian intern yang dapat diandalkan untuk pengendalian } \\
\text { pelaksanaan program/kegiatan sesuai prosedur. }\end{array}$ & 156 & 86,6 & Tinggi \\
\hline 16 & $\begin{array}{l}\text { Pemanfaatan sistem informasi akuntansi daerah untuk menghasilkan } \\
\text { laporan keuangan }\end{array}$ & 139 & 77,2 & Sedang \\
\hline 17 & $\begin{array}{l}\text { Pemanfaatan SAKIP untuk menghasilkan LAKIP (Laporan Kinerja } \\
\text { Instansi Pemerintah) }\end{array}$ & 135 & 75 & Sedang \\
\hline 18 & Evaluasi peningkatan ekonomi dan efisiensi penggunaan anggaran & 159 & 88,8 & Tinggi \\
\hline 19 & $\begin{array}{l}\text { Evaluasi peningkatan efektivitas manfaat program sesuai tuntutan } \\
\text { dan kebutuhan masyarakat }\end{array}$ & 165 & 91,6 & Tinggi \\
\hline
\end{tabular}

Hasil penghitungan dapat diketahui bahwa penilaian skor pada variabel implementasi penganggaran berbasis kinerja secara umum yaitu skor Sedang / cukup baik sebanyak $52,8 \%$ sedangkan skor Tinggi sebanyak 44,4\%. Artinya mengindikasikan bahwa dalam implementasi penganggaran berbasis 
Analisis Implementasi... (Endang, Made, Syamsul)

kinerja di SKPD Kabupaten Karawang mulai dari persiapan, pelaksanaan dan pelaporan anggaran telah dilaksanakan tetapi masih belum maksimal, dan masih harus terus di kembangkan penggunaan system informasi untuk mengoptimalkan pembuatan laporan kinerja/keuangan.

Dari distribusi data Akuntabilitas Instansi Pemerintah Daerah (Y), yaitu terlebih dahulu menentukan skor maksimal yaitu sebesar 180, skor minimal sebesar 36, nilai median sebesar 108 nilai kuartil 1 sebesar 72 dan nilai kuartil 3 sebesar 144. Kemudian membuat batas-batas skor untuk masing-masing kategori.

Range skor dari keempat kategori:

Tinggi : (Kuartil $3 \leq \mathrm{x} \leq$ Skor maksimal) $=$ $144-180$

Sedang: $($ Median $\leq x<$ Kuartil 3) $=108-144$
Rendah: $($ Kuartil $1 \leq \mathrm{x}<$ Median $)=72$ $-108$

Sangat Rendah: (Skor Minimal $\leq \mathrm{x}<$ Kuartil 1) $=36-72$

Analisis hasil tanggapan responden dilakukan dengan terlebih dahulu menyusun tabel jawaban responden atas item-item dalam pernyataan menurut variabel, dimensi dan indikator, dari penilaian responden terhadap Akuntabilitas Instansi Pemerintah Daerah. Atas dasar tabel ini akan dideskripsi penilaian responden terhadap akuntabilitas instansi pemerintah daerah yang terdiri dari Akuntabilitas Keuangan, Akuntabilitas Manfaat dan Akuntabilitas Prosedural.

Tabel 2

Penilaian Tim Penilai Kinerja Kabupaten Karawang terhadap SKPD Mengenai Akuntabilitas Instansi Pemerintah Daerah

\begin{tabular}{|c|c|c|c|c|}
\hline NO & ITEM & SKOR & PERSENTASE & KATEGORI \\
\hline 1 & $\begin{array}{l}\text { Integritas keuangan SKPD terhadap perundangan } \\
\text { mengacu pada Permendagri Nomor } 13 \text { Tahun } 2006 .\end{array}$ & 169 & 95,5 & Tinggi \\
\hline 2 & $\begin{array}{l}\text { Integritas keuangan SKPD terhadap perundangan } \\
\text { mengacu pada Keputusan Bupati Nomor } 26 \text { Tahun } \\
2006 \text {. }\end{array}$ & 172 & 95,5 & Tinggi \\
\hline 3 & $\begin{array}{l}\text { Integritas keuangan SKPD terhadap perundangan } \\
\text { mengacu pada Undang-Undang Nomor } 17 \text { Tahun } \\
2003 \text {. }\end{array}$ & 174 & 96,67 & Tinggi \\
\hline 4 & $\begin{array}{l}\text { Integritas keuangan SKPD terhadap perundangan } \\
\text { mengacu pada Undang-Undang Nomor } 1 \text { Tahun } 2000 .\end{array}$ & 167 & 92,7 & Tinggi \\
\hline 5 & $\begin{array}{l}\text { Pengangkatan/penunjukkan pegawai dalam } \\
\text { pelaksanaan kegiatan sesuai dengan kapabilitas yang } \\
\text { dimiliki. }\end{array}$ & 156 & 86,6 & Tinggi \\
\hline 6 & $\begin{array}{l}\text { Pegawai melaksanakan kegiatan dengan taat sesuai } \\
\text { peraturan }\end{array}$ & 155 & 86,11 & Tinggi \\
\hline 7 & $\begin{array}{l}\text { Kesesuaian penerimaan keuangan dengan target } \\
\text { penerimaan yang ditetapkan. }\end{array}$ & 121 & 67,22 & Sedang \\
\hline 8 & $\begin{array}{l}\text { Prosedur penyimpanan keuangan dilakukan pada } \\
\text { lembaga keuangan perbankan yang dimiliki } \\
\text { pemerintah daerah }\end{array}$ & 170 & 94,4 & Tinggi \\
\hline 9 & $\begin{array}{l}\text { Ketepatan pengeluaran keuangan sesuai dengan kas } \\
\text { budget yang ditetapkan. }\end{array}$ & 158 & 87,78 & Tinggi \\
\hline 10 & $\begin{array}{l}\text { Kesesuaian kemampuan pegawai dalam melaksanakan } \\
\text { kegiatan terhadap sasaran hasil yang ditetapkan. }\end{array}$ & 170 & 94,4 & Tinggi \\
\hline 11 & $\begin{array}{l}\text { Kesesuaian kepatuhan pegawai dalam melaksanakan } \\
\text { kegiatan dengan ketentuan yang berlaku dengan } \\
\text { memberikan laporan kegiatan }\end{array}$ & 167 & 92,78 & Tinggi \\
\hline 12 & $\begin{array}{l}\text { Kemampuan pegawai mendukung pencapaian hasil } \\
\text { kerja yang diinginkan }\end{array}$ & 170 & 94,4 & Tinggi \\
\hline
\end{tabular}


JRKA Volume 3 Isue 2, Agustus 2017: 1 - 19

\begin{tabular}{|c|c|c|c|c|}
\hline 13 & $\begin{array}{l}\text { Kemampuan pegawai memanfaatkan sumberdaya yang } \\
\text { ada. }\end{array}$ & 149 & 82,78 & Tinggi \\
\hline 14 & $\begin{array}{l}\text { Kesesuaian prosedur pelaksanaan kegiatan dengan } \\
\text { prosedur yang berlaku dan dengan kondisi sosial di } \\
\text { daerah setempat. }\end{array}$ & 172 & 95,56 & Tinggi \\
\hline 15 & $\begin{array}{l}\text { Kesesuaian pelaksanaan kegiatan dengan etika yang } \\
\text { berlaku di daerah setempat. }\end{array}$ & 163 & 90,56 & Tinggi \\
\hline 16 & $\begin{array}{l}\text { Kesesuaian pelaksanaan kegiatan dengan prosedur dan } \\
\text { kepastian hukum yang berlaku }\end{array}$ & 176 & 97,78 & Tinggi \\
\hline 17 & $\begin{array}{l}\text { Kesesuaian pelaksanaan kegiatan dengan ketaatan } \\
\text { pada prosedur dan keputusan politis yang berlaku }\end{array}$ & 152 & 84,4 & Tinggi \\
\hline
\end{tabular}

Hasil penghitungan dapat diketahui bahwa penilaian skor pada variabel Akuntabilitas Kinerja Instansi Pemerintah secara umum yaitu skor Tinggi sebanyak 91,7\% sedangkan skor Sedang sebanyak $8,3 \%$. Artinya mengindikasikan bahwa sudah dilakukannya akuntabilitas keuangan, akuntabilitas manfaat dan akuntabilitas prosedur secara lengkap dan sesuai dengan peraturan perundangan yang telah ditetapkan.

Hasil pengumpulan data dengan mempergunakan kuesioner berskala Likert menghasilkan data dengan skala pengukuran ordinal. Agar dapat diolah dengan analisis regresi yang mensyaratkan data minimal berskala interval, maka data yang diperoleh dalam bentuk skala pengukuran ordinal, terlebih dahulu ditransformasikan ke dalam bentuk skala pengukuran interval dengan menggunakan metoda successive interval, yang kemudian dipergunakan jumlah nilai item berskala interval untuk setiap variabel penelitian. Dalam penelitian ini, pengaruh implementasi penganggaran berbasis kinerja terhadap akuntabilitas instansi pemerintah daerah dikaji dengan menggunakan analisis regresi linear sederhana.

Dalam penelitian ini, hipotesis yang diajukan adalah terdapat pengaruh dari implementasi penganggaran berbasis kinerja terhadap akuntabilitas instansi Pemerintah Daerah Kabupaten Karawang. Pengaruh Implementasi Penganggaran Berbasis Kinerja (X) terhadap Akuntabilitas Instansi Pemerintah Daerah (Y) pada SKPD di Kabupaten Karawang dianalisis dengan menggunakan teknik analisis regresi linear sederhana. Analisis regresi linear sederhana terdiri dari: persamaan regresi yang meliputi intersep/konstanta dan koefisien regresi; pengaruh antar variabel; dan koefisien determinasi yang menunjukkan besarnya variasi variabel dependen yang dapat dijelakan oleh variabel independen. Model pengaruh antar variabel dimodelkan sebagai berikut:

$$
\mathrm{Y}=\beta_{0}+\beta_{1} \mathbf{X}+\mathrm{e}
$$

dimana:

$\mathrm{Y}=$ Akuntabilitas Instansi Pemerintah $\mathrm{X}=$ Implementasi Penganggaran Berbasis Kinerja

$\mathrm{e}=$ Residu Model

$\beta_{0}=$ intersep

$\beta_{1}=$ koefisien regresi

Persamaan di atas menggambarkan hubungan fungsional antara Implementasi Penganggaran berbasis Kinerja $(\mathrm{X})$ sebagai variabel penyebab terhadap Akuntabilitas Instansi Pemerintah pada Pemerintah Daerah Kabupaten Karawang (Y) sebagai variabel akibat. Dengan menggunakan data berskala interval hasil transformasi Metode Successive Interval dan proses pengolahan data analisis regresi sederhana melalui software IBM SPSS Ver. 24.0 diperoleh hasil sebagai berikut: 
Mode I Sum mary

\begin{tabular}{|l|r|r|r|r|}
\hline Model & R & R Square & $\begin{array}{l}\text { Adjusted } \\
\text { R Square }\end{array}$ & $\begin{array}{r}\text { Std. Error of } \\
\text { the Estimate }\end{array}$ \\
\hline 1 & $.299^{\mathrm{a}}$ & .089 & .063 & 6.92 \\
\hline
\end{tabular}

a. Predictors: (Constant), X (Implementasi Penganggaran Berbasis Kinerja)

b. Dependent Variable: $Y$ (A kuntabilitas Instansi Pemerintah)

ANOV A

\begin{tabular}{|c|c|c|c|c|c|c|}
\hline Model & & $\begin{array}{l}\text { Sum of } \\
\text { Squares }\end{array}$ & $\mathrm{df}$ & Mean Square & $\mathrm{F}$ & Sig. \\
\hline \multirow[t]{3}{*}{1} & Regression & 159.827 & 1 & 159.827 & 3.340 & $.076^{a}$ \\
\hline & Residual & 1627.039 & 34 & 47.854 & & \\
\hline & Total & 1786.867 & 35 & & & \\
\hline
\end{tabular}

a. Predictors: (Constant), $\mathrm{X}$ (Implementasi Penganggaran Berbasis Kinerja)

b. Dependent Variable: $Y$ (Akuntabilitas Instansi Pemerintah)

Coefficients ${ }^{\mathrm{a}}$

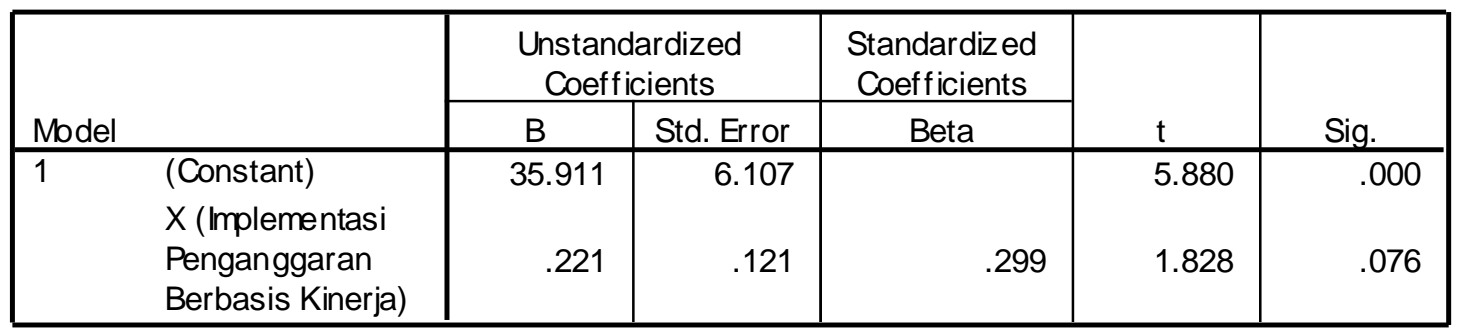

a. Dependent Variable: Y (Akuntabilitas Ins tansi Pemerintah)

Gambar 2

\section{Hasil Analisis Regresi Linear Sederhana}

Berdasarkan hasil perhitungan koefisien korelasi diketahui bahwa nilai korelasi antara Implementasi Penganggaran Berbasis Kinerja dengan Akuntabilitas Instansi Pemerintah Daerah sebesar 0,299. Besarnya koefisien korelasi ini kalau diimplementasikan terhadap Pedoman Penafsiran Koefisien Korelasi masuk dalam kategori pengaruh yang lemah (Sugiyono, 2016: 149). Sehingga besarnya determinasi menunjukkan bahwa Implementasi Penganggaran Berbasis Kinerja berpengaruh lemah terhadap Akuntabilitas Instansi Pemerintah Daerah, yaitu sebesar 0,0894 atau $8,94 \%$. Uji signifikansi koefisien korelasi ini dapat dilihat pada $\mathrm{F}_{\text {hitung }}=$ $3.340<\mathrm{F}_{\text {tabel }}=4,130$ yang berarti tidak signifikan pada taraf signifikansi $\alpha=0,05(0,076<0,05)$. Namun, dapat diterima atau signifikan pada taraf signifikansi $\alpha=0,10$ dengan $F_{\text {hitung }}=$ $3,340>\mathrm{F}_{\text {tabel }}=2,859$ yang berarti signifikan pada taraf signifikansi $\alpha=$ $0,10(0,076<0,10)$.

Berdasarkan hasil perhitungan koefisien regresi pengaruh Implementasi Penganggaran Berbasis Kinerja terhadap Akuntabilitas Instansi Pemerintah Daerah di atas, 
persamaan model regresi linear sederhana yang dihasilkan adalah:

$$
\begin{gathered}
Y=\beta_{0}+\beta_{1} X+e \\
Y=35,911+0,221 X+e
\end{gathered}
$$

dimana:

$\mathrm{Y}=$ Akuntabilitas Instansi Pemerintah

$\mathrm{X}=$ Implementasi Penganggaran Berbasis

Kinerja

e $=$ Residu Model

$\beta_{0}=$ intersep $=35,911$

$\beta_{1}=$ koefisien regresi $=0,221$

Intersep atau konstanta pada persamaan di atas, yaitu $\beta_{0}=35,911$ menunjukkan harga matematis dari Akuntabilitas Instansi Pemerintah jika Implementasi Penganggaran Berbasis Kinerja bernilai sama dengan nol (0). Konstanta ini menunjukkan pengaruh ratarata dari variabel Implementasi Penganggaran Berbasis Kinerja terhadap Akuntabilitas Instansi Pemerintah.

Koefisien regresi, yaitu $\beta_{1}=0,221$ menunjukkan besarnya respons penambahan skor Akuntabilitas Instansi Pemerintah jika skor Implementasi Penganggaran Berbasis Kinerja meningkat satu (1) satuan. Dengan kata lain, jika skor Implementasi Penganggaran Berbasis Kinerja meningkat sebesar 1 satuan, maka Akuntabilitas Instansi Pemerintah akan meningkat sebesar 36,132 satuan. Demikian pula sebaliknya, jika skor Implementasi Penganggaran Berbasis Kinerja menurun sebesar 1 satuan, Akuntabilitas Instansi Pemerintah akan menurun sebesar 35,690 satuan. Nilai koefisien regresi $\beta_{1}=0,221$ yang positif menunjukkan bahwa pengaruh Implementasi Penganggaran Berbasis Kinerja terhadap Akuntabilitas Instansi Pemerintah adalah searah.

Sebagaimana merujuk kepada Sugiyono (2016), koefisien korelasi menunjukkan kuatnya pengaruh satu variabel penyebab terhadap variabel akibat. Sedangkan besarnya pengaruh ditunjukkan oleh besarnya koefisien determinasi.

Uji hipotesis pengaruh Implementasi Penganggaran Berbasis Kinerja terhadap
Akuntabilitas Instansi Pemerintah dalam penelitian ini dilakukan secara deskriptif melalui koefisien korelasi yang dihasilkan dalam analisis regresi. Hal ini mengingat bahwa penelitian ini merupakan penelitian sensus yang meneliti seluruh instansi di lingkungan Pemerintah Daerah Kabupaten Karawang. Sebagaimana merujuk kepada Sugiyono (2016:112), uji hipotesis dalam penelitian sensus tidak dilakukan melalui hipotesis statistik $\left(\mathrm{H}_{0}\right.$ dan $\left.\mathrm{H}_{\mathrm{a}}\right)$. Demikian pula tidak menggunakan statistik uji seperti uji t dan taraf signifikansi $\alpha$.

Akuntabilitas pada penelitian ini terbatas pada Akuntabilitas Keuangan, Akuntabilitas Manfaat dan Akuntabilitas Prosedural karena tidak meneliti pada Akuntabilitas Hukum dan Kejujuran, Akuntabilitas Manajerial, Akuntabilitas Program. Dengan demikian lemahnya pengaruh Implementasi Penganggaran Berbasis Kinerja terhadap Akuntabilitas Instansi terbatas pada akuntabilitas keuangan, akuntabilitas manfaat dan akuntabilitas prosedur. Sedangkan pengaruhnya terhadap akuntabilitas keseluruhan belum dapat diketahui sesuai fokus masalah yang peneliti batasi.

Dari hasil pengolahan data dapat dikemukakan bahwa implementasi penganggaran berbasis kinerja memiliki pengaruh yang positif terhadap akuntabilitas instansi pemerintah pada Pemerintah Daerah Kabupaten Karawang. Hal ini menunjukkan bahwa peningkatan implementasi penganggaran berbasis kinerja akan meningkatkan akuntabilitas instansi Pemerintah Daerah Kabupaten Karawang. Derajat pengaruh implementasi penganggaran berbasis kinerja yang masih lemah juga menunjukkan bahwa akuntabilitas instansi pemerintah bergantung pula 
pada faktor-faktor lain di luar implementasi penganggaran berbasis kinerja. Faktor-faktor lain yang menentukan pengaruh implementasi anggaran berbasis kinerja terhadap akuntabilitas instansi pemerintah di antaranya adalah kepemimpinan dan kompetensi. Kepemimpinan menentukan seberapa baik atasan mampu mengarahkan perilaku organisasi dalam mencapai tujuannya. Dalam pencapaian akuntabilitas instansi, kepemimpinan yang baik akan mengarahkan implementasi anggaran berbasis kinerja pada pencapaian akuntabilitas instansi yang diharapkan. Selain kepemimpinan, kompetensi aparatur juga memegang peranan yang tidak kalah pentingnya. Aparatur yang memiliki kompetensi dalam penerapan/implementasi anggaran berbasis kinerja akan lebih mampu menerapkan prinsip transparansi, akuntabilitas dan value for money dalam merencanakan, melaksanakan serta menyusun laporan dan mengevaluasi anggaran instansi yang sesuai dengan tingkat akuntabilitas yang diinginkan. Dalam menjelaskan lemahnya pengaruh implementasi anggaran berbasis kinerja terhadap akuntabilitas instansi pemerintah daerah di Kabupaten Karawang, kedua faktor ini seyogyanya dapat dilibatkan dalam penelitian lanjutan.

Lemahnya pengaruh implementasi penganggaran berbasis kinerja disebabkan selama ini SKPD di lingkungan Pemda Kabupaten Karawang masih berorientasi pada pencapaian penyediaan input dan output dari program-program yang direncanakannya. SKPD masih belum berorientasi pada outcome dalam wujud pencapaian manfaat atas program-program yang akan direncanakan. Hal ini membawa konsekuensi agar implementasi penganggaran berbasis kinerja dapat lebih efektif meningkatkan akuntabilitas instansi pemerintah maka SKPD perlu lebih mengoptimalkan outcome yang diharapkan dalam proses perencanaan anggaran. Demikian pula dalam kegiatan pelaksanaan maupun evaluasi atas kinerja pencapaian sasaran. Diharapkan implementasi penganggaran berbasis kinerja dalam penyelenggaraan Pemerintahan Daerah Kabupaten Karawang yang berorientasi manfaat akan meningkatkan akuntabilitas perangkat daerah dalam melaksanakan tugas pokok dan fungsinya serta meningkatkan dukungan dan partisipasi masyarakat demi tercapainya tujuan program pembangunan di Kabupaten Karawang.

Hasil kajian wawancara konfirmasi kepada Ketua Tim Penilai Kinerja Pemda Kab Karawang menunjukkan bahwa penilaian kinerja Kabupaten Karawang belum dilaksanakan secara optimal karena masih dalam tahap awal (pembentukan tim kinerja tanggal 5 Maret 2016), sehingga evaluasi dilaksanakan untuk tahun anggaran 2017 dan sosialisasi tim kinerja tentang dasar penilaian masih rendah sehingga tidak sepenuhnya efektif dapat dilaksanakan oleh SKPD bahwa konsentrasi masih pada 11 SKPD yaitu:

a. Dinas Pendidikan dan Kebudayaan;

b. Dinas Kesehatan;

c. Dinas Pertanian Tanaman Pangan;

d. Badan Pendidikan dan Latihan;

e. Dinas Koperasi, Perindustrian dan Perdagangan;

f. Dinas Peternakan;

g. Dinas Ketenagakerjaan dan Transmigrasi;

h. Badan Pelaksana Penyuluhan Pertanian, Perikanan dan Kehutanan;

i. Dinas Kehutanan dan Perkebunan;

j. Dinas Kelautan dan Perikanan; 
k. Dinas Perhubungan;

Kendala yang dihadapi dalam implementasi anggaran berbasis kinerja di Pemda Kabupaten Karawang adalah bahwa peraturan pemerintah/peraturan perundangundangan yang ada saat ini isinya tidak runut sehingga pada saat implementasi baik SKPD maupun tim penilai kinerja mengalami kendala/kesulitan sehingga mengakibatkan pengaruh implementasi penganggaran berbasis kinerja terhadap akuntabilitas instansi pemerintah daerah sangat kecil. Sarana prasarana untuk penilaian kinerja yang diberikan kepada tim masih belum memadai sehingga hasilnya belum optimal. Upaya yang dilaksanakan yaitu dengan:

1. Membuat peraturan-peraturan bupati dan keputusan bupati untuk menyusun juklas dan juknis sebagai penjabaran dari peraturan pemerintah atau permendagri sehingga akan memudahkan dan mengefektivkan implementasi penganggaran dalam rangka meningkatkan akuntabilitas.

2. Meningkatkan koordinasi antar SKPD terkait yang berhubungan dengan perencanaan, penganggaran dan evaluasi.

3. Meningkatkan sarana dan prasarana oleh tim kinerja dan SKPD.

\section{KETERBATASAN PENELITIAN}

1. Kesimpulan mengenai pengaruh implementasi anggaran berbasis kinerja terhadap akuntabilitas instansi hanya dapat diterapkan di Kabupaten Karawang.

2. Hasil penelitian tentang lemahnya pengaruh implementasi anggaran berbasis kinerja terhadap akuntabilitas instansi Pemerintah Daerah Kabupaten Karawang dibatasi oleh dasar pengukuran yang digunakan, yaitu:

a. Implementasi anggaran berbasis kinerja diukur sebagai implementasi prinsip value of money dan pengawasan dalam anggaran pada setiap tahapan dalam siklus anggaran yang meliputi: persiapan anggaran, pelaksanaan anggaran, serta pelaporan dan evaluasi anggaran.

b. Akuntabilitas instansi dibatasi pada akuntabilitas keuangan, akuntabilitas manfaat, dan akuntabilitas prosedural.

3. Hasil penelitian tentang lemahnya pengaruh implementasi anggaran berbasis kinerja pada instansi Pemerintah Daerah Kabupaten Karawang dibatasi pula oleh instrumen yang digunakan, yang berkaitan dengan: subjektivitas penilaian responden yang dapat disebabkan oleh: kurangnya pemahaman atas pertanyaan, salah menafsirkan pertanyaaan, sikap mengabaikan pentingnya penelitian, dan sikap tidak jujur dari responden. Hal ini telah diusahakan untuk dikurangi melalui upaya peneliti untuk menjelaskan maksud penelitian dan pertanyaan yang diajukan serta penegasan peneliti untuk menjaga kerahasiaan responden.

\section{KESIMPULAN}

Pengaruh

Penganggaran Berbasis Kinerja terhadap Akuntabilitas Instansi Pemerintah pada Pemerintah Daerah Kabupaten Karawang adalah sebesar $8,9 \%$ berdasarkan nilai determinasinya. Arah pengaruhnya positif, yang berarti perbaikan implementasi penganggaran berbasis kinerja akan meningkatkan akuntabilitas instansi. Pengaruh sebesar ini menunjukkan bahwa implementasi penganggaran berbasis kinerja belum cukup efektif meningkatkan akuntabilitas instansi 
sebagai akibat kurang dilibatkannya manfaat yang diharapkan dalam penganggaran dan sosialisasi dasar penilaian kinerja yang masih rendah.

\section{REKOMENDASI}

Untuk meningkatkan efektivitas implementasi penganggaran berbasis kinerja dalam peningkatan akuntabilitas instansi, disarankan kepada Pemerintah Daerah Kabupaten Karawang untuk mengoptimalkan outcome yang diharapkan dalam proses anggaran dan meningkatkan sosialisasi dasar penilaian kinerja. Disarankan kepada Pemerintah Daerah Kabupaten Karawang untuk mengevaluasi dan memperbaiki implementasi penganggaran berbasis kinerja, khususnya dalam menerapkan sistem akuntansi yang dapat diandalkan untuk pengendalian anggaran.

Dengan adanya faktor-faktor lain yang cukup besar pengaruhnya terhadap akuntabilitas instansi, disarankan kepada peneliti lanjutan untuk mengkaji faktorfaktor lain yang tidak dilibatkan, seperti: kepemimpinan dan kompetensi. Selain itu meneliti pula implementasi penganggaran berbasis kinerja berdasarkan pendekatan pengukuran lainnya, selain tahapan-tahapan dalam siklus anggaran.

\section{DAFTAR PUSTAKA}

Arikunto, 2016. Prosedur Penelitian Suatu Pendekatan Praktik. Jakarta: Rineka Cipta.

LAN RI - BPKP. 2011. Modul Pembelajaran Akuntabilitas Kinerja Instansi Pemerintah. Jakarta: Lembaga Administrasi Negara.

Mardiasmo. 2012. Otonomi dan Manajemen Keuangan Daerah. Yogyakarta: ANDI

Mardiasmo. 2012. Akuntansi Sektor Publik. Yogyakarta: ANDI.

Schiavo-Campo, S., and Tomasi, D., 2009. Managing Government Expenditure, Manila, Asia Development Bank.
Sugiyono, 2016. Statistika Untuk Penelitian. Bandung: Alfabeta.

Suparmoko, M. 2000. Keuangan Negara Dalam Teori dan Praktek. Yogyakarta: BPFE UGM.

Wahyuni, $\quad$ Trisacti. 2008. Penganggaran Berbasis Kinerja Pada Kementerian/Lembaga: Masih Harus Banyak Berbenah, Departemen Keuangan Republik Indonesia Direktorat Jenderal Anggaran (http://www.anggaran.depkeu. go.id/web-printlist.asp?ContentId=97).

\section{Dokumen:}

Undang-undang Nomor 32 Tahun 2004 tentang Pemerintahan Daerah. Jakarta: Biro Humas Depdagri.

Undang-undang Nomor 33 Tahun 2004 tentang Perimbangan Keuangan Pusat dan Daerah. Jakarta: Biro Humas Depdagri.

Permendagri Nomor 13 Tahun 2006 tentang Pedoman Pengelolaan Keuangan Daerah. Bandung: Fokusmedia.

Peraturan Pemerintah Nomor 58 Tahun 2006 tentang Pengelolaan Keuangan Daerah. Bandung: Fokusmedia.

Peraturan Daerah Kabupaten Karawang Nomor 18 Tahun 2007 tentang Organisasi Perangkat Daerah Kabupaten Karawang.

Tim Studi Pengembangan Sistem Akuntabilitas Kinerja Instansi Pemerintah (SAKIP)

Kementrian Pendayagunaan Aparatur Negara Deputi Bidang Akuntabilitas Aparatur Evaluasi Kinerja Instansi 
Berbasis Evalusi Program, Jakarta Mei 2015

Tim Studi Pengembangan Sistem Akuntabilitas Kinerja Instansi Pemerintah (SAKIP) Kementrian Pendayagunaan Aparatur Negara Deputi Bidang Akuntabilitas Penyusunan Penetapan Kinerja. Jakarta: Mei 2015.

Tim Studi Pengembangan Sistem Akuntabilitas Kinerja Instansi Pemerintah (SAKIP) Kementrian Pendayagunaan Aparatur Negara Deputi Bidang Akuntabilitas Pelatihan Pengantar dan Perencanaan Evalusi LAKIP, Jakarta: Mei 2015.

Tim Studi Pengembangan Sistem Akuntabilitas Kinerja Instansi Pemerintah (SAKIP) Kementrian Pendayagunaan Aparatur Negara Deputi Bidang Akuntabilitas Sistem Akuntabilitas Kinerja Instansi Pemerintah (SAKIP) Dalam Kontelasi Peraturan Perundangan Manajemen Sektor Publik, Jakarta: Mei 2015. 